\title{
Teaching Management And Sustainable Utilization Of Water Resources At Infant Level In Primary Schools In Zimbabwe: Challenges And Opportunities
}

\author{
Thondhlana Saiden (DPhil) \\ Associate Professor. Zimbabwe Open University. \\ Department of Educational Studies. \\ Mangizvo V. Remigios (PhD) \\ Associate Professor. Zimbabwe Open University. \\ Department of Geography and Environmental Studies.
}

\begin{abstract}
Water has become an inadequate resource as a result of population and economic growth, climate change, pollution and other challenges. This is impacting on social, economic and environmental wellbeing. Education about water issues at all levels is pertinent to equip people with knowledge, skills and values of its management and sustainable utilization. Young children have a tendency of wasting water because of lack of knowledge of its management and sustainable utilization. The study aimed at establishing how knowledge, skills and attitudes of the management and sustainable utilization of water resources were being transmitted to school pupils in the infant grades in primary school. Furthermore the study wanted to find out the extent to which the curriculum content addressed the management and sustainable utilization of water resources. The study was conducted in the infants section of primary schools in the City of Gweru. It was qualitative in nature and it employed document analysis, indepth interviews and questerviews to gather data. The sample of seven teachers in the infant section was purposively selected as these were the people with the requisite information. The study established that the infant syllabi has inadequate content for the management and sustainable utilization of water resources. The education system in Zimbabwe has not put in place mechanisms and strategies to pass on information to the young learners. Teachers have not been capacitated to deal with this aspect of the curriculum. The methods used in schools to inculcate the content are suitable for the age levels. The study concluded that the content and teaching of management and sustainable utilization were not adequate. The materials to complement the teaching were relevant. The study recommends the assessment methods need to be practical so as to establish the attitudes and skills acquired and that adequate content has to be injected into the curriculum.
\end{abstract}

Key words: Management and sustainable utilization, water, infant grade, curriculum, Zimbabwean primary school.

\section{INTRODUCTION}

Water is one of the most precious resources that exist especially considering that only $3 \%$ of the global water is fresh (Mishra and Dubey, 2015). At a global level more than a billion people lack access to potable water, while more than two billion people do not have access to water (Mounir et al., 2015). These statistics present daunting challenges as water is central in determining the survival, health as well as welfare of human beings. The threats of climate change and variability have exacerbated the situation. Zimbabwe has experienced recurrent droughts since the turn of the new millennium (Food and Agricultural Organisation (FAO) 2015). This means both rural and urban communities have been exposed to shortages of 
water. Both rural and urban communities have therefore resorted to unreliable and unsafe water sources such as shallow wells. These have in turn exposed them to communicable diarrheal diseases such as cholera, dysentery and typhoid. In 2008-9 Zimbabwe experienced its worst cholera epidemic in living history that recorded a cumulative total of 98,592 cases and 4288 deaths by 31 July 2009 (Chirisa et al., 2015; Mason, 2009). Diarrheal diseases are however considered as ancient diseases which should not be affecting modern societies. Urban residents are drawing water from boreholes and wells just like their rural counterparts. There is a convergence between urban and rural life and this is resulting in ruralization of urban areas (Goodyear, 2014). What should actually be happening is the urbanization of rural areas.

Several urban areas in Zimbabwe are failing to manage water in a sustainable manner. Treated water is lost through leakages because the pipes and pumps were old and obsolete. The City of Mutare was losing $52 \%$ of treated water through leakages because pipes were old (New Zimbabwe, 2015). Chigumira and Mujere (2009) observe that Kadoma also experience severe water losses from water bursts as a result of old pipes that were laid in the 1970s and have not been replaced. Kwidini (2007) contends that pumps and pipes have a lifespan of between 15 and 20 years. Almost all cities in Zimbabwe have not been able to replace their water systems due to lack of financial resources. Even though urban residents have been exposed to crippling water shortages through leakages, they have not been involved in solving the problem. It is however unfortunate that most urban areas in the country have clearly communicated proactive water conservation policies. According to Kusena et al. (2016) the City of Gweru for instance resorts to ad hoc water conservation and demand measures that included fixing leaks or bursts and reducing water pressure only during drought periods. Gumbo and van der Zaag (2002) also observe that municipalities are reactive when it comes to water conservation and demand management. This is always used as a last and desperate resort during water shortages.

It is apparent that in the face of water shortages residents have limited knowledge about water conservation and demand management measures. In a study conducted by Kusena et al. (2016) in Gweru City it was observed that residents had limited knowledge about water conservation and demand management measures in place. They went to conclude that this was because Gweru City did not sensitize residents on efficient water use. Ignorant residents do not realize the need to report water leakages. They feel water belongs to the city council yet it is their own resource. Kusena et al (2016) argue that residents did not want to conserve water because they lacked a sense of ownership.

Whilst a lot of attention on conservation is paid at community and university level very little has been done at the initial stages of academic life. It is imperative to introduce young learners to water conservation and management issues because they have the necessary practical experience which helps them to access its conceptual complexity at a preliminary level (Samaltani and Christidou, 2013). It is observed that learners develop their knowledge, values and the way they reason in relation to the environment they live in. Education should therefore be designed in a manner that helps learners to grapple with problem recognition and solving skills. They should also be taught to use natural resources such as water in a sustainable manner. The main thrust in early childhood learning should be the holistic development of learners. Formative education should result in the development of a society that is able to ensure a "sustainable" future which appreciates environmental problems and develops positive attitudes and effective behavior in dealing with those problems. 
This study was motivated by the need to include learners in early childhood classes in water management and conservation as this points to a sustainable future that is sustainable development. The study aimed at establishing how knowledge, skills and attitudes of the management and sustainable utilization of water resources was being transmitted to school pupils in the infant grades in primary school. Furthermore the study wanted to find out the extent to which the curriculum content addressed the management and sustainable utilization of water resources.

\section{REVIEW OF RELATED LITERATURE}

The review of related literature will encompass the conceptual framework, the theoretical framework and a review of empirical evidence.

\section{Conceptual framework}

The conceptual framework will entail clarifying the concepts Early Childhood Development and sustainable utilisation of water resources and management of water resources.

\section{Early Childhood Development (ECD)}

Chigumbu and Chikutuma (2013) cite Morrison (1995) explaining ECD as exploring the characteristics of the first stages of life lasting from zero to about eight years. This is a period before formal learning extending to the first years of formal primary school education. It is a comprehensive approach to policies and development programmes for young children as well as their parents and caregivers. The concept accepts that a child does not grow and develop in a vacuum, but rather in a community, thus community based services that include health, nutrition, education, water and environmental sanitation of infants. ECD is therefore, a process through which the young children grow and strive physically, mentally, socially, emotionally and morally.

Katz (1996 p.137) cited by Chigumbu and Chikutuma (2013) define ECD as ' a set of concepts, principles, and facts that explain, describe and account for the process involved in change from immature status and functioning. ECD falls into three categories namely infant stage (03years), the pre-school face (4-5years) and the early primary school stage (6-8 years).

Mutswanga and Nyamande (2013) posits that ECD improves young children's capacity to develop and learn. Hyde and Karibu (2003) cited by Mutswanga and Nyamande (2013) contend that ECD includes early socialisation, education and readiness for school, as well as, the provision of basic health care, adequate nutrition, nurturing and stimulation within a caring environment. The ECD stage is an age of supreme importance for emotional, intellectual and social development.

\section{Sustainable Utilisation of water resources and Management of water resources}

Epiney (2003) contend that sustainable use of freshwater refers to a use which guarantees that the existing freshwater can be maintained in quantity and quality for future generations. This means that the existing natural freshwater coming from the water sources should be maintained and managed in such a way that in quantity and quality the water can continue to be used as freshwater resources for people. The approach implies protecting measures in order to distribute the water resources in an appropriate way without damaging the availability of the resource itself.

Schnoor (2010) defines sustainability as supplying or being supplied with water for life or perhaps more precisely as the continual supply of clean water for human uses and for other living things. This implies sufficient availability of water into the foreseeable future. 
Russo and Fisher (2014) view water management as the control and movement of water resources to minimise damage to life and property and maximising efficient beneficial use. The CSR Annual Report (1999) views sustainable use of water as the efficient water management practices. Katko, Petri and Schwartz (2012) referring to integrated water resources management posits that it is a process which promotes the coordinated development and management of water... in order to maximize and resultant economic and social welfare in an equitable manner without compromising the sustainability of vital ecosystem.

\section{The Theoretical framework of the study}

The study was premised on the theory of experiential learning propounded by Kolb (1984) and Dewy (1997). Justification for the selection of the theories was their grounding in experiential learning which forms the base in teaching issues to change attitudes and inculcate practical skills like managing and sustainable utilisation of water resources particularly in pupils at early childhood and infant level. Kolb (1984, p.38) points out that learning is a process whereby knowledge is created through transformation of experience. Four strategies were postulated namely concrete experience (doing), reflective observation (reviewing) / reflecting on the experience) abstract conceptualisation where the learner attempts to conceptualise a theory or model and active experimentation (planning/trying out what was learnt).

Dewy (1997) postulates that experiential learning involves the teacher playing a facilitative and guide role. The teacher is to be a partner in the learning process, guiding students to independently discover meaning within the area. The assumption is that learners progress fast through doing the work not through mechanical drill and prefabricated material. Dewey (1997) believed it was essential to have ability to use skills rather than acquisition of predetermined set of skills.

Experiential learning would be ideal in teaching and learning of managing and sustainable utilisation of water resources where learners have to be given room to practice skills in managing and sustainable utilisation of water resources. Learners are supposed to be given room to discover for themselves experiment and learn through "hands on experience".

\section{Empirical review of related literature}

The empirical review of related literature constitutes approaches to water saving and education, methodology used in the inculcation of the material, water purification strategies, ways of assessing the mastery of the material and a study on preschool teachers beliefs and attitudes about whether water science and sustainable management of water could keep children's interest.

With regards approaches to water saving and education Obuk and Pequena (2018) enumerated the following; reusing or recycling water, laboratory testing of water from nearby, changing irrigation system from furrow irrigation to drip, turning classical tap system to a plutocell tap i.e. touch free system lavatories, self made open cola, hoe carbonation, pressurised irrigation, a flow reducer on tap and a bag full of water in the toilet flush tank in order to limit its capacity, installing water saving technologies at home to avoid water wasting individually, closing taps while not necessary and choosing shower instead of bathing and purification of water.

The Shellhabour City Council (2018) in a project involving 21 childcare centres in the Shellhabour local government area suggests the following activities or actions on water use. First the use of the eco cycle on washing machines and dishwasher and only run when full and use of a full sink of water to wash or soak art items rather use running water from the tap,. 
Secondly, establishing a newsletter to parents about actions the children are taking, investigating the opportunity to label bed sheets so they can be reused for the same child on consecutive days and increasing mulching of gardens to prevent evaporation to reduce gardens watering needs. Thirdly, conducting a water audit to eliminate unnecessary water use and comparing water bills when available, taking manual water meter readings at the end of the day and in the morning to establish if water is being lost outside business hours and ensuring timely repairs of identified leaks. Fourthly, purchasing water appliances with highest water efficiency ratings (using the WELS star rating scales), installing low flow taps including push taps to prevent water wastage through taps being left on and ensuring all toilets both staff and children are converted to dual flush toilets. Fifthly, installing a rain water tank with a gauge and connecting to toilets and washing machines. Sixthly, providing water cans for children to assist with watering the garden, encouraging children to collect and measure water in containers and encouraging general water play activities including fishing and washing up using a water tray. Seventhly, creating a signage to be placed above taps to remind children to turn off taps after use and collecting left over water from water play to water the garden and finally creating a water wall with recycled materials and use of buckets to collect water at the end so that it can be reused.

The United States Environmental Protection Agency (2018) offers a number of strategies for management of storm water. These include the following; green roofs, rain barrels and cisterns, permeable pavements, bio-retention areas, vegetated swales/dry swales, curb and gutter elimination, vegetated filter strips, sand and organic filters, constructed wetlands and Riparian buffers.

Material on water purification strategies is also quite crucial with regards sustainable use of water resources. Water Purification Solutions (2011) suggest the use of two Turnkey water treatment systems namely flocculation standard filtration and membrane filtration.

The above outlined issues could constitute material to be embraced in the curriculum for the ECD level. The material from Shellhabour City Council (2018) could to taken wholesomely yet the other material from other sources could be simplified. The study aimed at establishing how much of these strategies teachers knew about.

Pertaining methods to be used to transmit the material Obuk and Pequena (2018) suggest using active learning, problem-based learning and use of multimedia technology. Shellhabour City Council (2018) suggests use of discussions and story making using photos or drawing. Bourotzoglou, Emmanouloudis and Georyopoulos (2016) recommend the use of experiential educational activities. They pointed out that the negative attitudes displayed by teachers regarding equipping children at pre- school level about sustainable use of water and management of water resources could be addressed by staff developing them in experiential education. Assessment methods related to the above methods of delivery are practical and oral examinations.

Bourotzoglou, Emmanouloudis and Georyopoulos (2016) undertook a study of pre-school teacher beliefs and attitudes towards teaching water science and sustainable management of water. The study involved 128 pre-school teachers from Northern Greece who were interviewed. The study centred on the teachers willingness to improve their skills and knowledge on the scientific subject water and its sustainable management, their comfort in teaching these subjects and their familiarity with the content knowledge, pedagogical teaching methods of pre-school and environmental education. The findings of the study showed that pre-school teacher's attitudes and beliefs were positive but under certain conditions namely 
they did not have the willingness to spend time creating materials, they did not need more scientific knowledge, they did not consider children's experimentation as the best ways of learning, the "creative clutter" caused by experimentation annoyed them, they were not willing to engage in children's experimentation with water, watching what children do, what they say or ask and they did not consider more activities with water necessary. This study also aimed at establishing some of the issues investigated in the above study.

\section{METHODOLOGY}

The study used the qualitative research paradigm. Open ended questionnaires and document analysis were used as data gathering techniques. A case study design was adopted. Case study findings have a problem that they cannot be generalised to the entire population (Silverman, 2010). Only one cluster in the Gweru District, that is Bumburwi Cluster was used for this study. The study population was 36 teachers. A sample of 22 teachers purposively selected composed the informants. Syllabuses and text books were also analysed. A case study design was adopted. Data was collected after seeking for permission from the Ministry of Primary and Secondary Education. The study took three months. In analysing data Merriam's (2009) procedures of analysing data was used.

\section{FINDINGS}

The findings are presented beginning with biographical data of informants, findings on the content from informants, participants and document analysis, findings on the methods used and findings on the assessment strategies employed.

\section{Biographical data}

Table 1 shows the biographical data of the informants

Table 1: Biographical Data of the Informants $(\mathrm{N}=22)$

\begin{tabular}{|cl|c|c|c|c|c|c|}
\hline \multirow{2}{*}{ 1. Sex } & Male & Female & & & & \\
\cline { 2 - 7 } & 0 & 22 & & & & \\
\hline 2. & Age & $21-30$ & $31-40$ & $41-50$ & $51-60$ & $60+$ & \\
& & 1 & 2 & 14 & 5 & 0 & \\
\hline 3. & Teaching & $1-10$ & $11-20$ & $21-30$ & $31-40$ & $41-50$ & $51+$ \\
& experience & 9 & 5 & 5 & 3 & 0 & 0 \\
\hline 4. & Educational & ZJC & O'level & A'level & First degree & Masters & Other \\
& qualifications & 0 & 16 & 3 & 3 & 0 & 0 \\
\hline 5. & Status & Teacher & Senior & T.I.C & D/Head & Head & \\
& 5 & teacher & 0 & 0 & 0 & \\
& & 17 & & & & \\
\hline
\end{tabular}

Table 1 reveals that all informants are female teachers. This is the case in that infant teachers in Zimbabwe are mainly female teachers. Male teachers do not normally want to teach early childhood and infant grades. Maybe, because they take nursing of children to be duty of mothers. The ages of the informants ranged from 2 41-50 years. The teaching experience of the informants ranged from 1-40 years with the majority in the 1-10 year age range.

The educational qualifications of the informants ranged from O'level to first degree with the majority in the 0'level category. The status of the informants ranged from teachers to senior teachers with the majority in the senior teacher category. From the information it can be inferred that the majority of the teachers are mature and have adequate experience to provide reliable information. All the teachers are also standard qualified teachers according to Zimbabwean standards. 


\section{Availability of content on managing and sustainable use of water resources Informants and participants}

The majority of the informants were able to locate where information of water was found that is in the Science and Mathematics syllabus $(n=16)$. The $n=16$ who could not were not specific for they simply stated that the information was in the national syllabus with no further elaboration.

With regards the content addressing the issues of managing and sustainable utilisation of water resources only $n=4$ were able to state water conservation as a form of manageent. Most of the participants only mentioned either water or uses of water. Some stated water and the environment.

Pertaining adequacy of the content $n=19$ stated yes only $n=3$ stated the content was not adequate.

Regarding areas that needed to be reviewed only $n=2$ suggested areas like how to manage water and using water conservatively.

The participants in the interviews agreed in total with the views raised by informants above.

\section{Suitability of methodology of teaching}

With reference to suitability of methodology the majority of the informants $n=16$ indicates the methods were suitable with some giving example such as field trips, problem solving and profit method.

Three $(n=3)$ stated the methods were not suitable. On other methods that the informants felt were left out the $n=3$ who stated the methods were not suitable suggested the hands on approach. One $n=1$ suggested projects would help in driving home the content. The majority reflected nothing was left out. Participants in the interviews concurred with the views put forward by informants above.

\section{Suitability of assessment methods}

Pertaining suitability of assessment $n=21$ stated the assessment was suitable but only $n=1$ stated no idea. All the informants who stated the assessment was suitable could not proffer anything that was left out. Participants in interviews concurred with the views of the informants above.

\section{General comments}

The informants in the majority could not pass comments. Those who passed comments put forward such comments as content covered was too much for the grades and shortage of teaching resources.

\section{Document analysis findings}

The Zimbabwe Ministry of Primary and Secondary Education (2015) revealed that the ECD A had the following areas under water: 'sources of water';, 'sources of water can be dangerous';, 'water makes things wet' and 'water has different uses'. There was no material on managing and sustainable utilisation of water resources.

The ECD B has the following areas under the topic water: 'some plants and animals live in water'; 'some objects sink in water' and 'water flows'. There was no coverage of the material on managing and sustainable utilisation of water resources. 
The Grade 1 Mathematics and Science syllabus under the topic water had the following areas: 'some objects float in water'; 'water is used in many areas by people';, 'animals and plants';, 'water is dangerous' and 'water is colourless, ordourless and tasteless'. There was again no mention of managing and sustainable utilisation of water resources.

The Grade 2 syllabus had the following areas under water: 'water takes the shape of a container'; 'water is found in other environment' and 'water can be conserved;. This syllabus is the one which is a carrier of issues of managing and sustainable utilisation of water resources. One of the syllabus objective that was related to managing and sustainable utilisation of water resources was to apply scientific and mathematical concepts and skills for environmental sustainability. The methods to be used by teachers to drive home the material are educational tours, investigation, experimentation, projects, imitation and discovery. All these are quite suitable methods.

The assessment methods pointed out in the syllabus are; continuous assessment practical assessment and pencil and paper tests. Practical assessments are ideal for assessing managing and sustainable utilisation water resources.

Currently the ECD and Grade 1 have textbooks based on the syllabi. The Grade 2 syllabus does not have a textbook yet. The analysis of the two textbooks available reflect that pupils at ECD level are subjected to the following pictures of tanks, dam, well, borehole, tap with questions and instructions; what are these? What do we get from them and colouring of the pictures? There are also uses of water namely washing plates, children swimming, a ship moving on water with questions; what is the water used for and instructions to paint or colour the pictures (Mawere and Gutsu, 2012). The material in the textbook has nothing to do with managing and sustainable utilisation of water resources.

The Grade 1 textbook by Skinner, Nyamayedenga Chirume and Mhirimo (2017) has the following areas on water, flash back on where water is got at home, sinking and floating, plants and animals need water, people need water and water can be dangerous. There is no area that deals with managing and sustainable utilisation of water resources except water can be dangerous.

\section{DISCUSSION OF FINDINGS}

The findings on the content reflect that the teachers are not aware of the content to be included on issues on the sustainable utilisation of water resources and the management of water resources as pointed out in Obuk and Pequena (2018), Shellhabour City Council (2018), United States Environmental Protection Agency (2018) and Water Purification Solutions (2010). The curriculum has left out a lot of the issues pointed out in the sources reflected above except for the grade 2 syllabus. This is basically due to the fact that teachers are failing to be innovative. They restrict themselves to the syllabus and at the same time limit the pupils who in actual fact need to be extended. Both teachers and pupils are managing water and practise sustainable water utilisation on a daily basis. Zimbabwe's urban areas have been experiencing water shortages for a long time. This has forced families to train children to manage water and use it sustainably in the homes. Teachers simply do not want to think outside the box.

The findings on methods to be employed concur with views on methods pointed out by Obuk and Pequena (2018) except use of multimedia technology and Bourotzoglou, Emmanouloudis and Georyopoulos (2016). The teachers and the curriculum documents concur with the views of the authorities above. 
The findings on assessments methods to be employed in the curriculum documents and pointed out by teachers are quite suitable.

\section{CONCLUSIONS}

From the above findings the following conclusions could be drawn;

- The curriculum for ECD assumes that pupils at this level do not know much about water management, yet they are already managing water on a day to day basis in their homes.

- Teachers lack creativity when teaching water management and sustainable utilisation issues at the ECD. They must refer pupils to issues of leaking pipes, being responsible citizens who do not vandalise water systems and the hygiene issues, since ECD pupils contaminate water with their dirty hands.

- Ministry of Primary and Secondary Education curriculum at ECD has inadequate content on sustainable utilization of water resources and the management of water resources,

- Teachers exhibit inadequate knowledge of issues of sustainable utilization of water resources and the management of water resources. This cannot be generalised however, because these are the characteristics of only teachers from one cluster in Gweru District.

- Appropriate methods of delivering the material are being used.

- Appropriate assessment methods are being used.

\section{RECOMMENDATIONS}

The following recommendations can be advanced from the conclusions;

- That the Ministry of Primary and Secondary Education includes missing aspects in the curriculum on sustainable utilization of water resources and water management,

- Teachers must be practical and think outside the box and start teaching pupils their lived experiences, that is, what they encounter on a daily basis.

- That the teachers be staff developed on issues related to the sustainable utilization of water resources and management of water resources which is a crucial area.

- Further research could be carried out on beliefs and attitudes of infant teachers regarding the teaching of sustainable utilization of water resources and management of water resources.

\section{References}

20 January 2015, available at: http://www.newzimbabwe.com/news-20077-

Mutare+loses+half+its+water+to+leakages/news.aspx (accessed 30 September 2015).

Chigumira, E. and Mujere, N. (2009). Variability of urban water supply and demand, in Feyen, J., Shannon, K. and Neville, M. (Eds.), Water and Urban Development Paradigms: Towards an Integration of Engineering, Design and Management Approaches, CRC Press, London, 431-434.

Chigumira, E. and Mujere, N. (2009). Variability of urban water supply and demand, in Feyen, J., Shannon, K. and Neville, M. (Eds.), Water and Urban Development Paradigms: Towards an Integration of Engineering, Design and Management Approaches, CRC Press, London, 431-434.

Chirisa I, Nyamadzawo L, Bandauko E, Mutsindikwa N (2015) The 2008/2009 cholera outbreak in Harare, Zimbabwe: case of failure in urban environmental health and planning. Rev Environ Health 30(2), 117-124.

Chirisa I, Nyamadzawo L, Bandauko E, Mutsindikwa N (2015) The 2008/2009 cholera outbreak in Harare, Zimbabwe: case of failure in urban environmental health and planning. Rev Environ Health 30(2), $117-124$.

Dewy, J. (1997). Experience and Education. New York: MacMillan.

Dewy, J. (1997). Experience and Education. New York: MacMillan.

Food and Agriculture Organization (2015). Social Protection and Agriculture. Food and Agriculture Organization of the United Nations | Zimbabwe Newsletter. Issue 4. Available at FAO-ZW@fao.org; www.fao.org/africa/en/ 
Food and Agriculture Organization (2015). Social Protection and Agriculture. Food and Agriculture Organization of the United Nations | Zimbabwe Newsletter. Issue 4. Available at FAO-ZW@fao.org; www.fao.org/africa/en/

Goodyear, S. (2014). The 'Ruralization' of Urban Areas. Citylab. Available at: https://www.citylab.com/equity/2014/01/look-ruralization-urban-areas/8101/

Goodyear, S. (2014). The 'Ruralization' of Urban Areas. Citylab. Available at: https://www.citylab.com/equity/2014/01/look-ruralization-urban-areas/8101/

Gumbo, B. and Van Der Zaag, P. (2002). Water losses and the political constraints to demand management: the case of the City of Mutare. Physics and Chemistry of the Earth, 27(1), 805-813.

Gumbo, B. and Van Der Zaag, P. (2002). Water losses and the political constraints to demand management: the case of the City of Mutare. Physics and Chemistry of the Earth, 27(1), 805-813.

Kolb, D.A. (1984). Experiential Learning: Experience as the source of Learning and Development. Volume 1 Prentice Hall: Englewood Chiffs. N.

Kolb, D.A. (1984). Experiential Learning: Experience as the source of Learning and Development. Volume 1 Prentice Hall: Englewood Chiffs. N.

Kusena, W., Sumaiya, D., Heinz, B. and Chemura, A. (2016). Assessing Public Participation in Water Conservation and Water Demand Management in Water Stressed Urban Areas: Insights from the City of Gweru, Zimbabwe. Review of Social Sciences, 01(08), 30-43

Kusena, W., Sumaiya, D., Heinz, B. and Chemura, A. (2016). Assessing Public Participation in Water Conservation and Water Demand Management in Water Stressed Urban Areas: Insights from the City of Gweru, Zimbabwe. Review of Social Sciences, 01(08), 30-43

Kwidini, T. (2007). Water Shortage Looms in Harare. Mail and Guardian, 01 August 2014, available at: http://mg.co.za/article/2007-08-01-water-shortage-looms-in-harare (accessed 3 August 2016).

Kwidini, T. (2007). Water Shortage Looms in Harare. Mail and Guardian, 01 August 2014, available at: http://mg.co.za/article/2007-08-01-water-shortage-looms-in-harare (accessed 3 August 2016).

Managing and sustainable utilisation of water resources.

Managing and sustainable utilisation of water resources.

Mason, P.R. (2009). Zimbabwe experiences the worst epidemic of cholera in Africa. Journal of Infection in Developing Countries, 3(2), 148-151.

Mason, P.R. (2009). Zimbabwe experiences the worst epidemic of cholera in Africa. Journal of Infection in Developing Countries, 3(2), 148-151.

Mawere, V and Gatsi, R. (2012). ECD Time: Science and Discovery Work book. Play, learn, create, Harare: Zimbabwe Publishing House.

Mawere, V and Gatsi, R. (2012). ECD Time: Science and Discovery Work book. Play, learn, create, Harare: Zimbabwe Publishing House.

Merriam, S.B. (2009). Qualitative Research: A Guide to Design and Implementation. San Francisco: Jossey Bass.

Merriam, S.B. (2009). Qualitative Research: A Guide to Design and Implementation. San Francisco: Jossey Bass.

Mounir, Z.M., Gao, C.S., Moustapha, A.M. and Ma, C.M. (2014). Water resources management in Sub-Saharan Africa: A status review of Niger Republic Zakari Mahamadou. International Journal of Water, 8(3), 275-298.

Mounir, Z.M., Gao, C.S., Moustapha, A.M. and Ma, C.M. (2014). Water resources management in Sub-Saharan Africa: A status review of Niger Republic Zakari Mahamadou. International Journal of Water, 8(3), 275-298.

New Zimbabwe (2015). Mutare loses half its treated water through leakages. New Zimbabwe,

New Zimbabwe (2015). Mutare loses half its treated water through leakages. New Zimbabwe, 20 January 2015, available at: http://www.newzimbabwe.com/news-20077-

Mutare+loses+half+its+water+to+leakages/news.aspx (accessed 30 September 2015).

Silverman, D. (2010). Doing Qualitative Research, A Practical Handbook. London: Sage.

Silverman, D. (2010). Doing Qualitative Research, A Practical Handbook. London: Sage.

Skinner, D. Nyamayedenga, L., Chirume, F. and Mirimo, C. (2017). Ventures Primary Mathematics and Science Learner's Book1. Harare: College Press. 
Skinner, D. Nyamayedenga, L., Chirume, F. and Mirimo, C. (2017). Ventures Primary Mathematics and Science Learner's Book1. Harare: College Press.

Zimbabwe Ministry of Primary and Secondary Education (2015). Mathematics and Science Infant (Early Childhood Development-Grade 2, Syllabus, Harare: Curriculum Development Unit

Zimbabwe Ministry of Primary and Secondary Education (2015). Mathematics and Science Infant (Early Childhood Development-Grade 2, Syllabus, Harare: Curriculum Development Unit 